\title{
Comparison of Corticotrophin and Corticosteroid Response to Lysine Vasopressin, Insulin, and Pyrogen in Man
}

\author{
J. J. STAUB， J. S. JENKINS， J. G. RATCLIFFE，J. LANDON
}

British Medical fournal, 1973, 1, 267-269

\begin{abstract}
Summary
Plasma corticotrophin (ACTH) and corticosteroid levels in response to lysine vasopressin (LVP), insulin hypoglycaemia, and pyrogen have been compared in seven subjects with normal pituitary adrenal function. Intramuscular vasopressin was a weak stimulus to corticotrophin release, peak values lying within the range 49 to $141 \mathrm{pg} / \mathrm{ml}$. Insulin hypoglycaemia consistently caused a more noticeable increase, with peak levels between 114 and $364 \mathrm{pg} / \mathrm{ml}$, while pyrogen was the most powerful, corticotrophin levels rising to between 209 and $1,725 \mathrm{pg} / \mathrm{ml}$. Peak plasma corticosteroid levels showed less pronounced differences between the three tests, and correlated poorly with peak ACTH levels. Thus, relatively small acute changes in corticotrophin levels produce near-maximal adrenal stimulation. Under these conditions, plasma corticosteroid measurements do not accurately reflect circulating corticotrophin levels. These findings help to explain the physiological basis of several observations on the corticosteroid responses to these clinical test procedures.
\end{abstract}

\section{Introduction}

The corticosteroid responses to lysine vasopressin (LVP), insulin hypoglycaemia, and pyrogen have been used clinically as tests of hypothalamic-pituitary-adrenal function for many years. Several comparative studies of plasma corticosteroid levels during these tests have been reported in normal subjects and in patients with pituitary adrenal dysfunction (Jenkins and Else, 1968; Carroll et al., 1969; Jacobs and Nabarro, 1969; Jenkins et al., 1972). Corticotrophin (ACTH) responses to these stimuli have not, however, been compared partly because it is often assumed that plasma corticosteroid levels reflect circulating ACTH concentrations. During periods of acute pituitary stimulation, and when plasma ACTH levels exceed the adrenal threshold for maximal stimulation, this direct relation may no longer pertain. Accurate assessment of the pituitary response must then depend on direct measurement of plasma ACTH levels.

This paper reports the plasma immunoreactive ACTH and corticosteroid responses to intramuscular LVP, insulin, and pyrogen tests in seven patients with normal pituitary-adrenal function.

\section{Subjects and Methods}

Seven patients (two women and five men, aged between 16 and 55 years) volunteered for the tests. They showed no evidence of

Department of Chemical Pathology, St. Bartholomew's Hospital, London EC1A 7BE

J. J. STAUB, M.D., Visiting Research Fellow (Present Address: Medizinische Universitätspoliklinik, Departement für Innere Medizin, Hebelstrasse 1, CH-4056 Basel, Switzerland)

J. G. RATCLIFFE, M.SC., D.M., Lecturer

J. LANDON, M.D., Professor

Department of Medicine, St. George's Hospital, London S.W.1

J. S. JENKINS, M.D., F.R.C.P., Consultant Physician endocrine, hepatic, or renal disease, except one patient who had an isolated growth hormone deficiency but normal adrenocortical function. The tests were performed at intervals of two days in the order: LVP; insulin; pyrogen. All were started between 09.00 and 10.00 hours using an indwelling venous cannula inserted into a forearm vein at least $30 \mathrm{~min}$ previously. Two basal samples were taken. Synthetic LVP (Sandoz, 10 pressor units) was given by intramuscular injection and samples were taken every $15 \mathrm{~min}$ for $90 \mathrm{~min}$ (Gwinup, 1965; Brostoff et al., 1968). Soluble insulin (Organon, 0.15 units $/ \mathrm{kg}$ body weight) was injected intravenously (Greenwood et al., 1966) and samples were taken $30,45,60$, and 90 min later. Adequate hypoglycaemia was achieved in all subjects, the blood sugar falling to below $40 \mathrm{mg} / 100 \mathrm{ml}$, associated with sweating. Bacterial pyrogen (Organon, 0.005 $\mathrm{\mu g} / \mathrm{kg}$ body weight) was given intravenously together with aspirin (Jenkins and Else, 1968) and blood was taken 120,180, 240, and 360 min later. Samples were collected in cooled heparinized plastic syringes, separated immediately, deep frozen in dry ice, and stored at $-20^{\circ}$ until assay.

Plasma corticosteroids were determined by a modification of the method of Mattingly (1962) (Spencer-Peet et al., 1965). Interassay variation at levels between 10 and $30 \mu \mathrm{g} / 100 \mathrm{ml}$ was $0.8 \mu \mathrm{g}$ (S.D.). Plasma ACTH was measured by radioimmunoassay (Landon and Greenwood, 1968) after extraction with porous glass (Ratcliffe and Edwards, 1971). The antiserum used reacts with amino-acid sequences within the steroidogenic part of the molecule (amino-acids 1-24). All values are expressed relative to a natural human ATCH standard (Lerner et al., 1968). The coefficient of variation was $7 \%$ at a level of 1,000 $\mathrm{pg} / \mathrm{ml}$ (intra-assay) and $19 \%$ at a level of $153 \mathrm{pg} / \mathrm{ml}$ (interassay). All samples from a single subject were measured in the same assay to minimize methodological variations. The significance of differences between mean levels were analysed by Student's $t$ test (two-tailed) and linear regressions were calculated by the method of least squares.

\section{Results}

Changes in Plasma ACTH.-A small but significant increment in immunoreactive ACTH over the lowest basal level was found in all except one subject after LVP (table I). The peak responses generally occurred at $30 \mathrm{~min}$ and ranged between 49 and 141 $\mathrm{pg} / \mathrm{ml}$ (mean $95 \mathrm{pg} / \mathrm{ml}$ ). After insulin, peak ACTH levels ranged from 114 to $364 \mathrm{pg} / \mathrm{ml}$ (mean $256 \mathrm{pg} / \mathrm{ml}$ ) and occurred consistently at $45 \mathrm{~min}$. The smallest peak response occurred in patient 7 , in whom the test was terminated prematurely with intravenous glucose. The levels were still raised at 90 minutes in most subjects. The peak ACTH response to pyrogen was greater and more variable than that achieved after insulin (209 to $1,725 \mathrm{pg} / \mathrm{ml}$, mean $643 \mathrm{pg} / \mathrm{ml}$ ) and occurred either 2 or $3 \mathrm{hr}$ after the stimulus. The plasma ACTH levels had returned to normal by 4 to $6 \mathrm{hr}$ in all except one subject.

Changes in Plasma Corticosteroids. - After LVP, peak corticosteroid levels ranged from 16.9 to $28.7 \mu \mathrm{g} / 100 \mathrm{ml}$ (mean 23.5 $\mu \mathrm{g} / 100 \mathrm{ml}$ ) and occurred 30 to $45 \mathrm{~min}$ after the stimulus. After insulin, peak corticosteroid levels were achieved usually at 60 min, ranged from 18.9 to $35.3 \mu \mathrm{g} / 100 \mathrm{ml}$ (mean $26.7 \mu \mathrm{g} / 100 \mathrm{ml}$ ), and showed considerable overlap with the maximum levels after LVP. The rise in corticosteroid levels after pyrogen occurred at $2 \mathrm{hr}$ and reached maximum values 2,3 , or $4 \mathrm{hr}$ after the stimulus. Corticosteroid levels exceeded $20 \mu \mathrm{g} / 100 \mathrm{ml}$ after 
TABLE I-Plasma ACTH and Fluorogenic Corticosteroid Responses to the Three Tests

\begin{tabular}{|c|c|c|c|c|c|c|c|c|c|c|c|c|c|c|c|c|c|c|c|c|c|c|}
\hline \multirow{2}{*}{$\begin{array}{l}\text { Sub- } \\
\text { ject } \\
\text { No. }\end{array}$} & \multirow{2}{*}{$\begin{array}{l}\text { Age } \\
\text { and } \\
\text { Sex }\end{array}$} & & \multicolumn{7}{|c|}{ Response to Vasopressin (Time in $\mathrm{min}$ ) } & \multicolumn{6}{|c|}{ Response to Insulin (Time in min) } & \multicolumn{7}{|c|}{ Response to Pyrogen (Time in $\mathrm{min}$ ) } \\
\hline & & & -30 & 0 & 15 & 30 & 45 & 60 & 90 & -30 & $\mathbf{0}$ & 30 & 45 & 60 & 90 & -30 & 0 & 120 & 150 & 180 & 240 & 360 \\
\hline $\begin{array}{l}1 \\
2 \\
3 \ddagger \\
4 \\
5 \\
6 \\
7\end{array}$ & $\begin{array}{l}50 \mathrm{M} . \\
37 \mathrm{M} . \\
22 \mathrm{M} . \\
48 \mathrm{~F} \\
16 \mathrm{M} . \\
55 \mathrm{M} . \\
21 \mathrm{~F} .\end{array}$ & $\begin{array}{l}\text { ACTH* } \\
\text { C-St } \\
\text { ACTH } \\
\text { C-S } \\
\text { ACTH } \\
\text { C-S } \\
\text { ACTH } \\
\text { C-S } \\
\text { ACTH } \\
\text { C-S } \\
\text { ACTH } \\
\text { C-S } \\
\text { ACTH } \\
\text { C-S }\end{array}$ & $\begin{array}{l}59 \\
39 \\
10 \cdot 8 \\
33 \\
17 \cdot 4 \\
51 \\
13 \cdot 6 \\
61 \\
11 \cdot 7 \\
41 \\
22 \cdot 7 \\
45 \\
18 \cdot 4\end{array}$ & \begin{tabular}{l|l|}
101 \\
47 \\
$7 \cdot 0$ \\
24 \\
$12 \cdot 6$ \\
48 \\
$13 \cdot 6$ \\
94 \\
$13 \cdot 1$ \\
46 \\
$15 \cdot 5$ \\
69 \\
18.7
\end{tabular} & $\begin{array}{l}70 \\
= \\
= \\
\overline{41} \\
16.6 \\
97 \\
13.8 \\
49 \\
16.9 \\
91 \\
19.4\end{array}$ & $\begin{array}{c}104 \\
\overline{83} \\
25 \cdot 5 \\
55 \\
22 \cdot 1 \\
73 \\
26 \cdot 2 \\
141 \\
18 \cdot 6 \\
46 \\
15 \cdot 6 \\
112.6 \\
20 \cdot 9\end{array}$ & $\begin{array}{c}\overline{-} \\
\overline{57} \\
19 \cdot 1 \\
96 \\
22 \cdot 1 \\
80 \\
28 \cdot 7 \\
103 \\
13.8 \\
29 \\
10.9 \\
81 \\
23.0\end{array}$ & $\begin{array}{l}\frac{72}{55} \\
17 \cdot 7 \\
63 \\
15 \cdot 2 \\
74 \\
23 \cdot 0 \\
68 \\
11 \cdot 7 \\
23 \\
9 \cdot 5 \\
92 \\
28 \cdot 1\end{array}$ & $\begin{array}{l}= \\
67 \\
18 \cdot 2 \\
51 \\
10 \cdot 4 \\
= \\
= \\
= \\
=\end{array}$ & $\begin{array}{l}57 \\
23 \cdot 3 \\
74 \\
9 \cdot 4 \\
97 \\
22 \cdot 4 \\
44 \\
18 \cdot 6 \\
95 \\
15 \cdot 1 \\
51 \\
17 \cdot 5 \\
90 \\
17 \cdot 6\end{array}$ & $\begin{array}{l}96 \\
24 \cdot 2 \\
61 \\
6 \cdot 3 \\
79 \\
17 \cdot 6 \\
38 \\
14 \cdot 3 \\
93 \\
11 \cdot 4 \\
29 \\
12 \cdot 6 \\
73 \\
17 \cdot 8\end{array}$ & $\begin{array}{c}149 \\
19 \cdot 5 \\
94 \\
8 \cdot 8 \\
171 \\
18 \cdot 4 \\
82 \\
14 \cdot 3 \\
60 \\
9 \cdot 2 \\
34 \\
14 \cdot 7 \\
80 \S \\
17 \cdot 8\end{array}$ & $\begin{array}{c}\bar{Z} \\
272 \\
11 \cdot 9 \\
310 \S \\
25 \cdot 2 \\
364 \S \\
21 \cdot 4 \\
265 \\
16 \cdot 2 \\
2178 \\
24 \cdot 7 \\
114 \\
27 \cdot 0\end{array}$ & $\begin{array}{c}235 \\
35 \cdot 3 \\
282 \\
25 \cdot 1 \\
208 \\
25 \cdot 4 \\
184 \\
24 \cdot 7 \\
204 \\
18 \cdot 9 \\
109 \\
27 \cdot 4 \\
79 \\
25 \cdot 4\end{array}$ & $\begin{array}{c}103 \\
22 \cdot 3 \\
82 \\
22 \cdot 6 \\
120 \\
25 \cdot 8 \\
96 \\
27 \cdot 3 \\
130 \\
15 \cdot 7 \\
58 \\
26 \cdot 3 \\
67 \\
20 \cdot 5\end{array}$ & $\begin{array}{c}48 \\
15 \cdot 5 \\
159 \\
17 \cdot 6 \\
40 \\
9 \cdot 5 \\
64 \\
21 \cdot 4 \\
97 \\
18 \cdot 3 \\
49 \\
9 \cdot 4 \\
58 \\
24 \cdot 2\end{array}$ & $\begin{array}{c}- \\
73 \\
16.5 \\
45 \\
8 \cdot 0 \\
62 \\
22.9 \\
111 \\
15.4 \\
26 \\
6.9 \\
28 \\
23.4\end{array}$ & $\begin{array}{c}205 \\
33 \cdot 3 \\
362 \\
24 \cdot 0 \\
291 \\
26 \cdot 0 \\
362 \\
43 \cdot 6 \\
635 \\
22 \cdot 3 \\
515 \\
25 \cdot 0 \\
209 \\
33 \cdot 7\end{array}$ & $\begin{array}{l}393 \\
\text { 40.0 } \\
= \\
= \\
= \\
= \\
= \\
=\end{array}$ & $\begin{array}{c}1,725 \\
48 \cdot 3 \\
109 \\
29 \cdot 4 \\
696 \\
33 \cdot 0 \\
= \\
102 \\
19 \cdot 2 \\
230 \\
29 \cdot 2 \\
195 \\
51 \cdot 4\end{array}$ & $\begin{array}{c}\overline{-} \\
78 \\
17 \cdot 5 \\
356 \\
36 \cdot 3 \\
62 \\
38 \cdot 6 \\
92 \\
16 \cdot 2 \\
174 \\
29 \cdot 3 \\
62 \\
46 \cdot 6\end{array}$ & $\begin{array}{c}\bar{Z} \\
56 \\
5 \cdot 6 \\
281 \\
22 \cdot 3 \\
59 \\
20 \cdot 0 \\
39 \\
13 \cdot 8 \\
47 \\
19 \cdot 1 \\
48 \\
20 \cdot 6\end{array}$ \\
\hline
\end{tabular}

* ACTH in $\mathrm{pg} / \mathrm{ml}$.

$+\mathrm{C}-\mathrm{S}=$ Fluorogenic corticosteroids in $\mu \mathrm{g} / 100 \mathrm{ml}$.

8 Glucose administered intravenously.

$6 \mathrm{hr}$ in two subjects. The peak levels ranged between $22 \cdot 3$ and $51.4 \mu \mathrm{g} / 100 \mathrm{ml}$ (mean $37.2 \mu \mathrm{g} / 100 \mathrm{ml}$ ) and showed greater variation than the peak levels after the other two tests (chart). Subject 5, who had the greatest ACTH response to LVP and substantial increases after insulin and pyrogen, showed the lowest corticosteroid response to all three tests and a low normal level after the administration of exogenous ACTH in the form of Synacthen (250 $\mu \mathrm{g}$ intramuscularly).

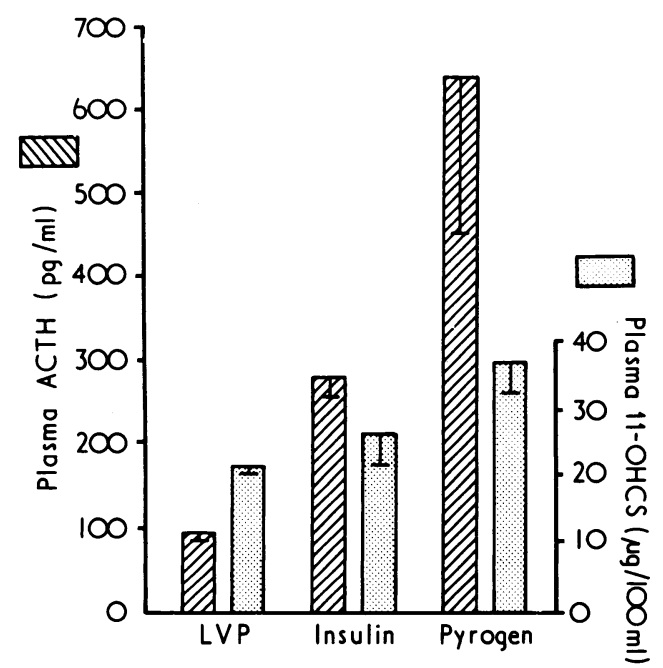

Peak plasma immunoreactive ACTH (hatched) and corticosteroid (stippled) levels after LVP, insulin hypoglycaemia, and pyrogen tests in seven subjects. Mean values are shown as columns and the standard error of the mean as vertical bars.

The maximum increments in plasma corticosteroids were not significantly different $(P>0.05)$ in the three tests and did not correlate with the maximum increments in plasma ACTH or the logarithm of the plasma ACTH levels.

\section{Discussion}

Previous data on the plasma ACTH responses to LVP, insulin hypoglycaemia, and pyrogen are summarized in table II. Several methods of ACTH assay have been used, some being insufficiently sensitive to measure basal levels. The wide scatter in reported values derives partly from the imprecision of many assays near their limits of sensitivity and partly from differences in the performance of the test procedures and variation in individual responses. There are no previous reports comparing ACTH levels achieved by these tests in the same patient.

The present study shows that the ACTH response to intra-
TABLE II-Peak Plasma ACTH Levels after Lysine Vasopressin, Insulin, and Pyrogen

\begin{tabular}{|c|c|c|c|c|}
\hline Tests and Authors & $\begin{array}{l}\text { Peak Plasma } \\
\text { ACTH Level } \\
\left(\mathrm{pg} / \mathrm{ml}^{*}\right)\end{array}$ & $\begin{array}{c}\text { Time of } \\
\text { Peak } \\
\text { (min) }\end{array}$ & $\begin{array}{l}\text { Method } \\
\text { of Assay }\end{array}$ & $\begin{array}{l}\text { No. of } \\
\text { Subjects }\end{array}$ \\
\hline $\begin{array}{l}\text { Lysine Vasopressin: } \\
\text { Gwinup et al.,1967 } \\
\text { Strott et al.,1967 } \\
\text { Berson and Yalow, 1968 } \\
\text { Landon and Greenwood, } \\
1968 \quad .10 \\
\text { Takebe et al., } 1968 \\
\text { Binoux et al., 1971 } \\
\text { Present study } \quad \text {. }\end{array}$ & $\begin{array}{c}180-450 \dagger \\
85-110 \\
28-130 \\
76-210 \\
40-69 \ddagger \\
16-60 \pm \\
49-141\end{array}$ & $\begin{array}{r}10-30 \\
45-60 \\
20-30 \\
= \\
\overline{15-30} \\
30-45\end{array}$ & $\begin{array}{l}\text { B.A. } \\
\text { R.I.A. } \\
\text { R.I.A. } \\
\text { R.I.A. } \\
\text { B.A. } \\
\text { B.A. } \\
\text { R.I.A. }\end{array}$ & $\begin{array}{l}7 \\
3 \\
3 \\
3 \\
5 \\
9 \\
7\end{array}$ \\
\hline $\begin{array}{l}\text { Insulin-Hypoglycaemia: } \\
\text { Berson and Yalow, } 1968 \\
\text { Landon and Greenwood, } \\
1968 \text {. } \\
\text { Donald, 1971; Donald } \text { et } \\
\text { al., } 1972 \\
\text { Ichikawa et al., } 1972 . \\
\text { Present study } . .\end{array}$ & $\begin{array}{l}110-360 \S \\
210-400 \\
147-431 \\
362+51 \cdot 7 \text { (S.E.) } \\
114-364\end{array}$ & $\begin{array}{l}30-60 \\
40 \\
45 \\
45 \\
45\end{array}$ & $\begin{array}{l}\text { R.I.A. } \\
\text { R.I.A. } \\
\text { R.I.A. } \\
\text { R.I.A. } \\
\text { R.I.A. }\end{array}$ & $\begin{array}{r}7 \\
3 \\
13 \\
5 \\
7\end{array}$ \\
\hline $\begin{array}{l}\text { Pyrogen: } \\
\text { Vance et al., 1962 } \\
\text { Takebe et al., 1966! } \\
\text { Takebe et al., 1966ף } \\
\text { Litta-Modignani and } \\
\text { Badoni, 1968 } \\
\text { Matsukura et al., i i } 1970 . \\
\text { Present study }\end{array}$ & $\begin{array}{l}\text { U.D. } \\
\text { U.D. } \\
110-160 \\
50-250 \\
100-1,150 \\
209-1,725\end{array}$ & $\begin{array}{l}3 \overline{-} \\
3 \mathrm{hr} \\
3 \mathrm{hr} \\
2-3 \mathrm{hr} \\
2-3 \mathrm{hr}\end{array}$ & $\begin{array}{l}\text { B.A. } \\
\text { B.A. } \\
\text { B.A. } \\
\text { B.A. } \\
\text { R.I.A. } \\
\text { R.I.A. }\end{array}$ & $\begin{array}{l}1 \\
3 \\
3 \\
5 \\
4 \\
7\end{array}$ \\
\hline
\end{tabular}
* Bioassay values are expressed in gravimetric terms assuming that $1 \mathrm{mg}$ of highly This may be only an approximate estimate of the potency of standard used by some authors.

Raised basal levels in all subjects.

Undetectable basal levels in most subjects.

Only subjects receiving adequate hypoglycaemia included (blood sugar less than $40 \mathrm{mg} / 100 \mathrm{ml}$ ).

II Pyrogen administered at 09.00 hours.

U.D. = Undetectable. B.A. = Bioassay. R.I.A. = Radioimmunaossay.

muscular LVP is smaller in magnitude and duration than that to insulin or pyrogen. The insulin test produced a more consistent ACTH response than either LVP or pyrogen, although the latter was the most powerful stimulus to ACTH release in six subjects and as potent as insulin in the remaining subject. The ACTH levels after pyrogen were similar to those found during thoracotomy (215-949 pg/ml: mean $478 \mathrm{pg} / \mathrm{ml}$, Ratcliffe and Staub, unpublished observations), cholecystectomy (Newsome and Rose, 1971), or electroconvulsive shock (Berson and Yalow, 1968). Thus, pyrogen provides the most potent test of ACTH secretion used clinically. These results contrast with some of the ACTH levels reported previously during pyrogen stimulation (table II). Such differences may be due to the different ACTH assay procedures and the use of less potent pyrogens-for example, piromen. It is of interest that the metyrapone test produces an ACTH response similar to insulin hypoglycaemia (Donald et al., 1972) but, since it acts through the negative feedback mechanism, it is not an appropriate indicator of stress responsiveness.

The plasma corticosteroid responses were within the range obtained in a large series of normal subjects (Jenkins et al., 
1972) and the peak levels achieved in all three tests showed considerable overlap. Thus, the hypothalamic-pituitary-adrenal response to LVP was better judged by the increment in corticosteroids rather than the change in plasma ACTH levels, whereas the ACTH responses to insulin and pyrogen were not accurately reflected by circulating corticosteroid levels. This suggests that a near-maximal adrenal response is achieved by quite small acute increments in plasma ACTH levels which is consistent with the finding (Landon et al., 1967) that a dose of $250 \mathrm{ng} \alpha^{1-24}$ ACTH intravenously produced a similar increment in plasma corticosteroids to that produced by a pharmacological dose $(250 \mu \mathrm{g})$. Corticosteroid and ACTH levels may also correlate poorly due to a suppressive effect of rising cortisol levels on further ACTH release through the negative feedback mechanism. This may operate especially on a weak stimulus such as vasopressin, but may also modify the ACTH response to pyrogen if the corticosteroid response is particularly great (as in subject 7).

The present finding of pronounced differences in ACTH release by LVP, insulin, and pyrogen helps explain several puzzling clinical observations. Thus, the vigorous stimulus to ACTH release by pyrogen could account for the failure of small doses of glucocorticoids or morphine to suppress the corticosteroid response to this test (Jenkins, 1968). The positive corticosteroid response to pyrogen noted after pituitary stalk section (van Wyk et al., 1960), might be explained by the release of sufficient corticotrophin releasing factor to bypass the stalk section locally or reach the pituitery via the general circulation. In patients with pituitary tumours, before and after irradiation, the corticosteroid response to LVP is more frequently abnormal than that to insulin, with the pyrogen test showing the highest proportion of normal responses (Jenkins and Else, 1968; Jenkins et al., 1972). A similar pattern is found in patients treated with long-term steroids (Daly et al., 1967; Jasani et al., 1967). Finally, it is known that patients with an impaired corticosteroid response to insulin may have a normal response to surgery or infection (Wynn, 1968). Again the strength of the various stimuli, rather than the pathways through which they operate, may explain these observations.

We thank the Medical Research Council for financial support.

\section{References}

Berson, S. A., and Yalow, R. S. (1968). Fournal of Clinical Investigation, 47, 2725.

Besser, G. M., et al. (1971). Fournal of Clinical Endocrinology, 32, 595.

Binoux, M., Gourmelen-Combourieu, M., Luton, J. P., Pham-Huu-Trung, M. T., and Girard, F. (1971). Acta Endocrinologica, 68, 1.

Brostoff, J., James, V. H. T., and Landon, J. (1968). Journal of Clinical

Carroll, B. J., Pearson, M. J., and Martin, F. I. R. (1969). Metabolism, 18, 476.

Daly, J. R., Myles, A. B., Bacon, P. A., Beardwell, C. G., and Savage, O. (1967). Annals of Rheumatic Diseases, 26, 18.

Donald, R. A. (1971). Fournal of Clinical Endocrinology, 32, 225.

Donald, R. A., Espiner, E. A., and Beaven, D. W. (1972). fournal of Endocrinology, 52, 517 .

Gwinup, G. (1965). Lancet, 2, 572.

Gwinup, G., Steinberg, T., King, C. G., and Vernikos-Danellis, J. (1967). Fournal of Clinical Endocrinology, 27, 927.

Greenwood, F. C., Landon, J;, and Stamp, T. C. B. (1966). Fournal of Clinical Investigation, 45, 429.

Ichikawa, Y., Nishikai, M., Kawagoe, M., Yoshida, K., and Homme, M.
(1972). fournal of Clinical Endocrinology, 34, 895.. (1972). Journal of Clinical Endocrinology, 34, 895 ..

Jacobs, H. S., and Nabarro, J. D. N. (1969). Quarterly fournal of Medicine, 38, 475 .

Jasani, M. K., et al. (1967), Quarterly fournal of Medicine, 36, 261.

Jenkins, J. S. (1968). In Memoirs of the Society for Endocrinology, 17, 205. Medicine, 41, 57 .

Jenkins, J. S., and Else, W. (1968). Lancet, 2, 940.

Landon, J., and Greenwood, F. C. (1968). Lancet, 1, 273.

Landon, J., James, V. H. T., Wharton, M. J., and Friedman, M. (1967). Lancet, 2, 697.

Lerner, A. B., Upton, G. V., and Lande, S. (1968). In Pharmacology of Hormonal Polypeptides and Proteins, ed. N. Back, L. Martini, and R. Paoletti, p. 203. London, Plenum Press. Litta-Modignani, R., and Badoni, M. (1968). Fournal of Endocrinology, 42, Matsukura, S. et al. (1970). Fournal of Laboratory and Clinical Medicine, 77,

Mattingly, D. (1962). Fournal of Clinical Pathology, 15, 374.

Newsome, H. H., and Rose, J. C. (1971). Fournal of Clinical Endocrinology, 33, 481 .

Ratcliffe, J. G., and Edwards, C. R. W. (1971). In Radioimmunoassay Methods, ed. K. E. Kirkham and W. M. Hunter, p. 502. Edinburgh,

Spencer-Peet, J., Daly, J. R., and Smith, V. (1965). Fournal of Endocrinology,

31, 235.
Strott, C. A., Nakagawa, K., Nan Kin H., and Nugent, C. A. (1967). fournal of Clinical Endocrinology, 27, 448.

Takebe, K., Setaishi, C., Hirama, M., Yamamoto, M., and Horiuchi, Y. (1966). Fournal of Clinical Endocrinology, 26, 437.

Takebe, K. et al. (1968). Fournal of Clinical Endocrinology, 28, 73.

Vance, V. K., Reddy, W. J., Nelson, D. H., and Thorn, G. W. (1962). fournal of Clinical Investigation, 41, 20.

van Wyk, J. J., Dugger, G. S. Newsome, J. F., and Thomas, P. Z. (1960). fournal of Clinical Endocrinology, 20, 160.

Wynn, V. (1968). In Memoirs of the Society for Endocrinology, 17, 225.

\section{Defects and Disabilities of Thalidomide Children}

\section{R. W. SMITHELLS}

British Medical fournal, 1973, 1, 269-272

\section{Summary}

The range of defects and disabilities in thalidomide children is very much wider than is generally realized. The defects of 154 children are described and classified. Their disabilities range from incapacitating to negligible.

\section{Introduction}

It has become customary to refer to "thalidomide children" as if they formed a homogeneous group with similar defects of more or less comparable severity. This is far from being the

\footnotetext{
Department of Paediatrics and Child Health, Leeds LS1 3ET

R. W. SMITHELLS, P.R.C.P., Professor of Paediatrics and Child Health, University of Leeds
}

case. The defects may be single or multiple and they may involve almost any system of the body. The perinatal mortality among these children was very high. The disabilities among survivors range from total incapacity to no disability at all.

In an earlier paper (Smithells, 1962) I reported on children with limb and ear defects ascertained on a population basis in Liverpool during the thalidomide epidemic. After publication a few further affected children were born. Further experience also made it possible to exclude with reasonable confidence a few cases in the earlier report which should not have been attributed to thalidomide. The revised original group comprises 29 children, 17 of whom were examined personally. Of these 29 children four were stillborn, eight died in the neonatal period, and one died later in the first year. The combined stillbirth and neonatal mortality was therefore $45 \%$. The causes of death were not known in all cases but included congenital anomalies of the heart, kidneys, and alimentary tract.

Since 1968 I have examined personally a further 159 children at the request of solicitors either to assess the extent of 